\title{
A late diagnosis of Pott's disease in an adolescent with psoas abscess
}

\author{
Pott hastalı̆̆ sonrası psoas absesi gelișen bir adolesan olgu
}

\author{
Hacer AKTÜRK, Selda HANÇERLI TÖRÜN, Bahar ÇALIŞKAN, Oğuz Bülent EROL, Feryal GÜN, Nuran SALMAN, \\ Ayper SOMER
}

\begin{abstract}
Psoas abscess is classified as primary or secondary according to presence or absence of the underlying focus of infection. Secondary psoas abscesses are much more common and tuberculosis of the spine (Pott's disease) is one of the leading predisposing diseases. Here we report a 16-year-old male presented with flank pain and abdominal distention, followed by spontaneous purulent drainage from lower back and lower abdomen. Eventually a painful swelling appeared below the right knee about one year after the appearance of the first symptoms. He was diagnosed as Pott's disease and secondary psoas abscess based on specific culture of draining pus, which yielded Mycobacterium tuberculosis and spinal magnetic resonance imaging (MRI) findings. Psoas abscess due to Pott's disease may show a nonspecific and chronic clinical course resulting in a late diagnosis and increased morbidity, as in the reported case. Clinicians in the endemic countries should be aware of this rare and challenging clinical entity.
\end{abstract}

Keywords: Psoas abscess, Pott's disease, tuberculosis, Differential diagnosis.

Hacer Aktürk (鼡, Selda Hançerli Törün, Bahar Çalışkan, Nuran Salman, Ayper Somer

Department of Pediatric Infectious Diseases,School of Medicine, Istanbul University, Istanbul, Turkey

e-mail: hacergunakturk@gmail.com

Oğuz Bülent Erol

Department of Radiology, School of Medicine, Istanbul University, Istanbul, Turkey

Feryal Gün

Department of Pediatric Surgery, School of Medicine, Istanbul University, Istanbul, Turkey

Submitted/Gönderme: 20.05 .2015

Accepted/Kabul: 13.08 .2015

\section{ÖZET}

Psoas abseleri altta yatan enfeksiyon odağının olup olmamasına göre primer ve sekonder olarak sinıflandırılmaktadır. Sekonder psoas abseleri daha sık görülür. Pott hastalığı olarak da bilinen vertebra tüberkülozu psoas abselerinin önde gelen nedenlerinden biridir. $\mathrm{Bu}$ yazıda, ilk olarak böğür ağrısı ve karında şişlik yakınmaları gelişen 16 yaşındaki bir erkek hasta tanıtılmaktadır. $\mathrm{Bu}$ yakınmaları takiben sırt ve karın bölgesinde kendiliğinden akıntı gelişmiş ve nihayetinde ilk yakınmalardan yaklaşık 1 yıl sonra sağ diz altı bölgesinde ağrı ve şişlik oluşmuştur. Hastaya, akıntının spesifik kültüründe Mycobacterium tuberculosis üremesi ve spinal MRI bulguları ile Pott hastalığına sekonder psoas absesi tanısı konulmuştur. Pott hastalığına sekonder gelişen psoas abselerinde kronik ve belirsiz klinik süreçler görülebilir. Bu durum ise, hastamızda olduğu gibi tanıda gecikmeyle sonuçlanabilir. Özellikle tüberkülozun endemik olduğu ülkelerde klinisyenlerin bu nadir ve tanısı karışıklık yaratabilen hastalığı akılda tutmaları gerekmektedir.'

Anahtar kelimeler: Psoas absesi, Pott hastalığı, tüberküloz, Ayıric1 tanı.

\section{Introduction}

Psoas abscess (PA), was first defined by Mynter in 1881 and referred to as psoitis. It is a collection of pus in the iliopsoas compartment [1]. Traditionally it is classified into primary psoas abscess with no obvious focus of infection, and secondary psoas abscess occurring with direct spread of infection from contiguous structures like the gastrointestinal tract, the urinary tract or the spine. In developing countries, tuberculosis of spine so called Pott's disease is still commonly reported as underlying focus of infection $[2,3]$. Its incidence is also increasing in industrialized countries among some risk groups $[4,5]$. Psoas abscess secondary to Pott's disease is often associated with a delayed 
diagnosis due to its insidious onset and nonspecific clinical presentation, causing considerable morbidity. Herein, we report a 16-year-old immunocompetent male who presented with lower back and a soft tissue mass over the right iliac fossa. He was diagnosed as tuberculosis of the spine and unilateral psoas abscess with a 1 year delay. At that time that he had also developed osteomyelitis and abscess of the right tibia.

We intend to point out the importance of considering tuberculosis (TB) in patients with psoas abscess, with the hope to contribute to the prevention of delays in diagnosis and treatment of such cases.

\section{Case Report}

A-sixteen-year old male was referred to pediatric infectious diseases department with complaints of lower back and right flank pain, intermittent spontaneous purulent drainage from a soft tissue mass over the right iliac fossa and lower back, and swelling and pain on the right knee. His first complaint was low back and right flank pain that started 1 year ago. . Subsequently, having a soft tissue mass over the right iliac fossa had motivated him to seek medical treatment 10 months ago. From that moment on he had been evaluated by a pediatric surgery department. On computerized tomography (CT) imaging of the abdomen, an abscess sited on right iliac fossa had been realized and drained by percutaneous placement of a catheter together with antibiotic treatment. He had continued to complain about pain and intermittent spontaneous purulent drainage from lower back and right lower iliac fossa (lower abdomen). Aspiration by a needle or drainage by a catheter had been repeated several times. He had also been given several antibiotic treatments, with no benefit. Lastly, pain and gradually appearing swelling on the right knee started three months ago. He denied fever, night sweats and significant weight loss. He had no weakness and continued to work in a textile factory. His medical history was unremarkable. There was no history of exposure to TB. On physical examination, his weight and height were in between 3rd-10th percentile. His vital signs were normal. He had a BCG scar. The lungs were clear on auscultation. He had mild tenderness and palpable soft tissue mass on the right iliac fossa with a catheter draining purulent material (Figure 1). He had also mild point tenderness over the lumbar spine with scars indicating past needle aspirations. Neurological assessment was normal. Extremity examination revealed a fluctuating swelling with a diameter of $3 \times 3 \mathrm{~cm}$ just below the right knee (Figure 2). Laboratory evaluation of the patient was as follows: Hemoglobin: $10.1 \mathrm{~g} / \mathrm{dL}$, white blood cell count: $7.3 \times 10^{9} / \mathrm{L}$, erythrocyte sedimentation rate: $76 \mathrm{~mm} / \mathrm{h}, \mathrm{C}$ reactive protein: $52 \mathrm{mg} / \mathrm{dL}$ (0-5), IgG: $1594 \mathrm{mg} / \mathrm{dL}$. Biochemical tests were all normal. Anti-HIV and Brucella Wright agglutination were negative. Tuberculin skin test was measured as $15 \mathrm{~mm}$. An interferongamma related assay test was found to be positive. Chest $\mathrm{X}$ ray was normal. Magnetic resonance imaging (MRI) revealed osteomyelitis and spondylodisciitis on L2, L3 and S1 vertebra and right sided psoas abscess. Furthermore, osteomyelitis and an abscess of $15 \times 17 \mathrm{~mm}$ on proximal tibia were visible on MRI of the right knee. A four drug regimen of antituberculous treatment (isoniazid, rifampicin, ethambutol, pyrazinamide) was commenced. Subsequently, specific culture of purulent material draining through the catheter on the right lower abdomen yielded Mycobacterium tuberculosis complex. Antimicrobial susceptibility testing was performed for the following four antituberculous drugs and the isolate was found to be susceptible to all of them Isoniasid $(2,5 \mu \mathrm{g} / \mathrm{ml})$, Rifampicin $(0,1 \mu \mathrm{g} / \mathrm{ml})$, Streptomycin $(2 \mu \mathrm{g} / \mathrm{ml})$, Ethambutol $(2,5 \mu \mathrm{g} / \mathrm{ml})$. After the first month of anti-tuberculous treatment, complaints of the patient were resolved completely with increasing appetite and weight gain of 2 kilograms.

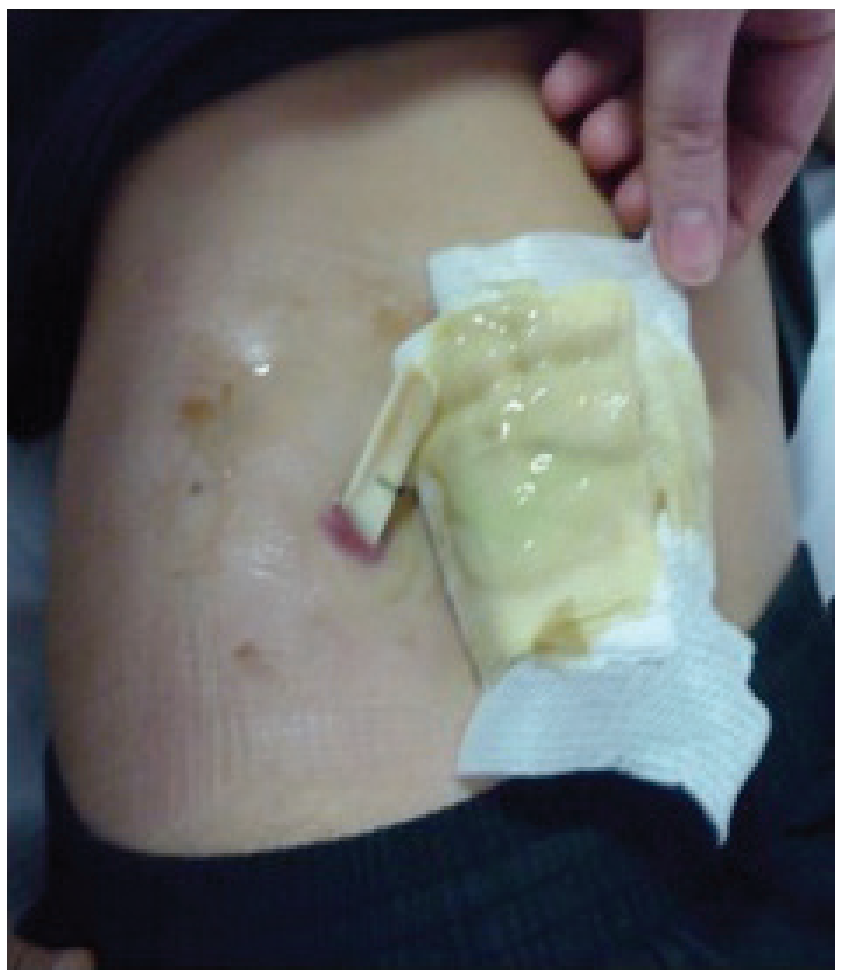

Figure 1. Purulent material draining through the percutaneous catheter on the right iliac fossa. 


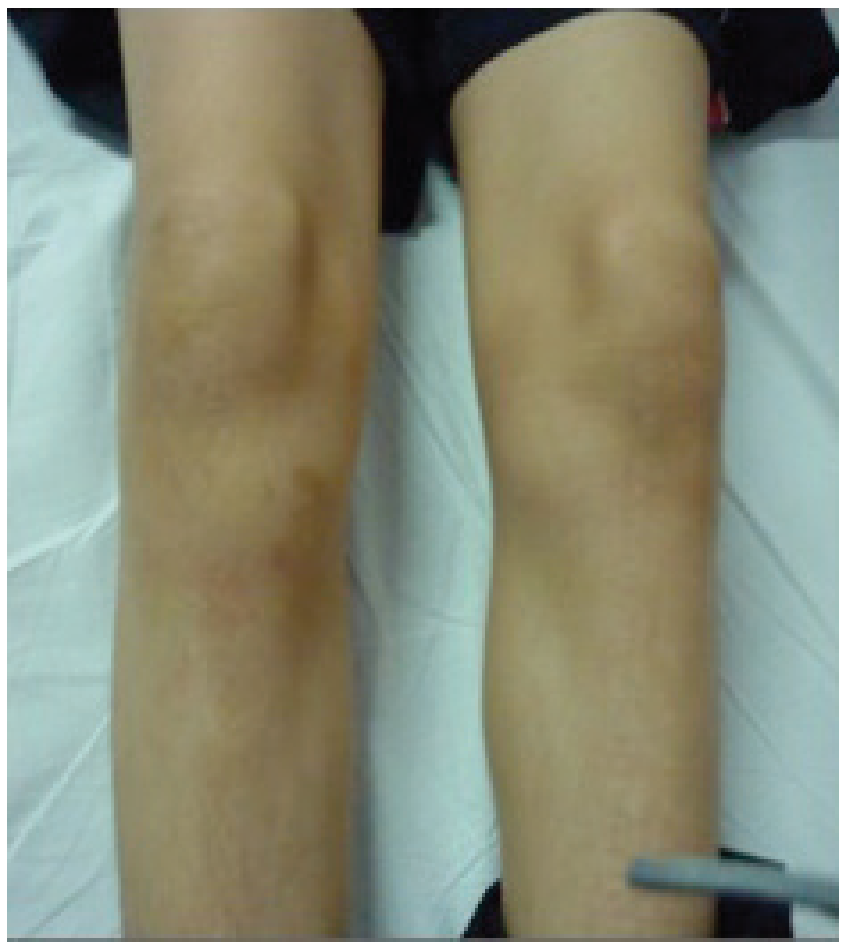

Figure 2. Tender swelling just below the right knee.

\section{Discussion}

Pott's disease or TB of the spine is an insidious disease commonly presenting with progressive local back pain. Fever, weight loss and constitutional symptoms may not be seen $[5,6]$. PA is one of the complications of Pott's disease, due to close anatomical placement. Because paraspinal abscesses may develop in $>50 \%$ of spinal TB cases, the identification of PA requires prompt evaluation of the spine as primary source of infection [7]. Truly incidence of PA remains unknown but it has probably increased, especially secondary ones, due to improvement in diagnostic modalities and recurrence of tuberculosis in industrialized countries [8]. Frequency of secondary psoas abscess has been reported to be $78 \%$ in a cohort of 124 patients from Spain source of infection being tuberculosis in $12 \%$ of patients, and majority were of skeletal origin [9]. This rate would be expected higher in tuberculous endemic countries.

Diagnosis of PA is still a challenge for clinicians. Especially when tuberculosis is the source of infection, a high index of suspicion is mandatory. Because, it may come out with a long term subclinical presentation, nonspecific symptomatology, chronic and relatively less aggressive clinical course than other types of secondary PA. In the study from Spain mentioned above the delay between onset of symptoms and diagnosis was found to be significantly greater in tuberculous PA than that found in other types of PA (61 days vs. 21 days; $p=0.03$ ) [9].. Similarly, frequency of fever and leukocytosis was reported to be significantly less in patients with tuberculous PA. Correspondingly, fever and leukocytosis was absent in our patient. He had a nonserious back pain for 2-3 months as subclinical presentation. Although he had a 1 year-delay between onset of symptoms and diagnosis, his general condition was good enough to permit him to keep going to work.

Risk factors have been defined both for spinal TB and PA [9-11], like immunosuppression, HIV infection and exposure history to TB. There was no underlying disease causing immunosuppression in our patient. He denied any known exposure to TB. His family screen for TB was negative. Working in a textile workshop may be accepted as a risk factor for TB in our country, which is endemic for TB.

Radiologic modalities namely ultrasonography, CT and MRI have facilitated the diagnosis of PA. Among them CT is considered as gold standard [12]. Ultrasonography is an easily available first step screening technique, but it has lower sensitivity and specificity than CT [13]. We also utilized MRI due to its advantage in determining pathologies of the spine. Microscopy and culture of the infected material sampled by the aid of either ultrasound or CT-guided percutaneous catheter drainage, which is also therapeutic or needle aspiration is the gold standard for the diagnosis of tuberculous PA. When microbiologic techniques remain negative, TB may also be diagnosed by compatible clinical findings and favorable response to empiric antituberculous treatment [9]. In the present case, gram staining of purulent abscess material revealed profuse polymorphonuclear leukocytes and acid fast staining was negative. Mycobacterium tuberculosis was identified in the specific tuberculosis culture.

Psoas abscess may be treated mostly by antimicrobial therapy plus percutaneous drainage, antimicrobial therapy alone, especially when small size of PA is the concern, or antimicrobial therapy plus surgery, in occurrence of chambered or multiloculated abscesses [9,12]. Adjuvant surgical treatment may be needed in cases of spinal TB with spinal cord compression, spinal instability or neurologic deficits [14]. Abscesses of our patient had been drained several times and he had already a percutaneous catheter when he admitted to our department. He had also been given antibiotic therapies before admission. Antituberculous treatment was commenced based on his compatible clinical presentation, positive tuberculin skin test and interferongamma related assay. Positive TB culture confirmed the 
diagnosis. He had no neurological pathologic findings so that no surgical intervention was needed. Although a 6-month treatment course is recommended for spinal TB, duration of therapy may be prolonged if the response to therapy is deemed slow. Response to treatment may be assessed by improvement in pain, mobility, general wellness, weight and neurological deficits, if exist. Radiologic improvement is not expected early, so usually not considered to be helpful in monitoring therapy [15]. Appropriate antituberculous therapy with or without surgical intervention has favorable prognosis in spinal TB and PA [5,9]. Medical treatment of our patient was prolonged to 1 year, with no residual radiologic or clinical pathology at the end.

High clinical suspicion is the major step to diagnose PA secondary to spinal TB. Myobacterium tuberculosis infection should be strongly considered in patients with PA who have risk factors like TB exposure history, HIV infection, and immunosuppression. It should be remembered that only living in a TB endemic country is also a risk factor. Poor response to antibiotic treatment and drainage should also remind us Myobacterium tuberculosis in differential diagnosis, to prevent long diagnostic delay.

\section{References}

1. Mynter H. Acute psoitis, Buffalo Med Surg J 1881; 21: 202-10.

2. Turunç $\mathrm{T}$, Turunç $\mathrm{T}$, Demiroğlu YZ, Colakoğlu S. Retrospective evaluation of 15 cases with psoas abscesses. Mikrobiyol Bul 2009;43:121-5.

3. Altıntaş N, Türkeli S, Yılmaz Y, Sarıaydın M, Yaşayancan N. A rare case of tuberculosis psoas abscess. Eur J Gen Med 2012;9:159-61.

4. Janssens JP, De Haller R. Spinal tuberculosis in a developed country: A review of 26 cases with special emphasis on abscesses and neurologic complications. Clin Orthop $1990 ; 257: 67-75$.
5. Maron R, Levine D, Dobbs TE, Geisler WM. Two cases of Pott's disease associated with bilateral psoas abscesses: case report. Spine 2006 15;31:E561-64. do1: 10.1097/01. brs.0000225998.99872.7f

6. Nussbaum ES, Rockswold GL, Bergman TA, et al. Spinal tuberculosis: A diagnostic and management challenge. J Neurosurg 1995;83:243-47.

7. Pertuiset E, Beaudreuil J, Liote F, et al. Spinal tuberculosis in adults. A study of 103 cases in a developed country, 1980 1994. Medicine 1999;78:309-20. 0025-7974/99/7805-0309/0

8. Berge VM, Marie S, Kuipers T, Jansz AR, Bravenboer B. Psoas abscess: report of a series and review of the literature. Neth J Med 2005;63:413-16.

9. Lopez VN, Ramos MJ, Meseguer V, et al. Microbiology and outcome of iliopsoas abscess in 124 patients. Medicine (Baltimore). 2009; 88:120-30. do1: 10.1097/ MD.0b013e31819d2748

10. Penado S, Espina B, Francisco Campo J. Abscess of the psoas muscle. Description of a series of 23 cases. Enferm Infecc Microbiol Clin 2001;19:257-60.

11. Van den Berge $M$, de Marie S, Kuipers T, Jansz AR, Bravenboer B. Psoas abscess: report of a series and review of the literature. Neth J Med 2005;63:413-16.

12. Santaella RO, Fishman EK, Lipsett PA. Primary vs. secondary iliopsoas abscess: presentation, microbiology and treatment. Arch Surg 1995;130:130913. doi:10.1001/ archsurg.1995.01430120063009

13. Zissin R, Gayer G, Kots E, Werner M, Shapiro-Feinberg M, Hertz M. Iliopsoas abscess: a report of 24 patients diagnosed by CT. Abdom Imaging 2001;26:533-39. doi: 10.1007/ s002610000201

14. Fitzgerald D, Haas DW. Mycobacterium tuberculosis. In: Mandell GL, Bennett JE, Dolin R, editors. Mandell, Douglas, and Bennett's: Principles and Practice of Infectious Diseases. 6th ed. Philadelphia: Elsevier Churchill Livingstone, 2005:2852-86.

15. Boxer DI, Pratt C, Hine AL, et al. Radiological features during and following treatment of spinal tuberculosis. Br J Radiol 1992;65:476-79. doi:http://dx.doi.org/10.1259/0007-1285$65-774-476$ 